\title{
A hora da estrela: por uma leitura nordestina
}

Luciano Barbosa Justino $^{1}$

A arte só é interpretável pela lei de seu movimento, não por invariantes. Determina-se na relação pelo que ela não é. O caráter artístico específico que nela existe deve deduzir-se, quanto ao conteúdo, do seu Outro.

Theodor Adorno

A verdadeira crítica deve ter a força de voltar-se contra nossos próprios critérios de justiça e consenso, já que ela se pergunta se nossa forma de vida não é mutilada a ponto de orientar-se por valores resultantes de distorções patológicas.

Vladimir Safatle

Há, pois, mais pessoas no céu e na terra dos indios do que sonham nossas antropologias.

Eduardo Viveiros de Castro

Meu objetivo neste artigo é pensar A hora da estrela, de Clarice Lispector, como um livro aporístico de uma ética do diálogo intercultural, razão pela qual a novela de 1977 ocupa um lugar singular dentro da poética da autora, indiscutivelmente uma das mais relevantes da literatura brasileira, cuja atualidade não para de nos levar além e a exigir de nós sempre novas abordagens, novos estratégias de leitura, novos modos de entrar e sair de nós mesmos e de concebermos nossas relações com os outros.

A hora da estrela abre uma nova dimensão na grande obra de Clarice, de "uma nova Clarice, exterior e explícita", como bem o disse Eduardo Portella (1981, p. 9), dimensão esta que, penso, potencializa uma nova política da escrita em relação àquilo que Benedito Nunes considerou uma

\footnotetext{
${ }^{1}$ Doutor em letras e linguística e professor da Universidade Estadual da Paraíba (UFPB), Campina Grande, Paraíba, Brasil. E-mail: lucianobjustino@hotmail.com
} 
"inevitável abstração de particularidades locais, de dados sociais, e, por fim, dos elementos objetivos da realidade" (2009, p. 114).

Se, em virtude da morte da autora, tal dimensão não pôde realizar-se plenamente, restando como potencialidade inexplorada de sua obra, $A$ hora da estrela não deixa de colocar questões instigantes para a literatura contemporânea sobre os processos de semiotização do "real" - "mas que diabo quer dizer isso?" -, e de suas fissuras, além de, o que é para mim mais relevante, indiciar suas premissas sobre o encontro com a alteridade.

Por isso, pretendo pensar A hora da estrela a partir de duas implicações éticas, do que doravante chamarei ética da escrita e ética do encontro com a alteridade. Na primeira, sua inserção crítica no contexto da literatura brasileira da segunda metade da década de 1970, com especial atenção para o debate em torno do lugar e do papel do escritor sob os governos Médici/Geisel, ainda praticamente intocada pela crítica, por sua melhor crítica. Na segunda, os modos de semiotização da produção de subjetividade dos pobres na obra da autora, não menos intocada pela crítica, que não discute em profundidade a ambivalência incômoda quanto ao encontro com a alteridade de Macabéa.

Se, na primeira, a crítica clariceana não deixa de chamar atenção para a problematização da literatura realista do período, acionando a ironia como instância discursiva desconstrutora; na segunda, pouco se tem explorado as bases heurísticas com as quais a autora nomeia a feia e nordestina Macabéa, servindo a ironia, sob este aspecto, como uma espécie de salvo conduto político que faculta o silenciamento da monstruosidade de Macabéa, como tentarei demonstrar.

Na primeira, confrontar a literatura com seus próprios termos como ponto de fuga a uma exigência de realismo por demais invasiva; na segunda, seguir até o limite a sugestão de Theodor Adorno (1988) de levála a confrontar-se com o fetichismo da mimesis que ela quer evitar ao tempo em que o reinventa à revelia de si mesma.

A alteridade de Macabéa, a "agonia" do narrador em relação à alteridade de Macabéa, quero pensá-la colocando toda vez um "local" de fala, de uma enunciação marcadamente nordestina, porque acredito que toda crítica intercultural tem que ser a crítica de uma fala "local", em virtude de o diálogo entre as culturas e suas formas de vida conter sempre o risco de reterritorializar a diferença sob a forma estigmatizante do clichê, o que $A$ hora da estrela demonstra à mancheia, sem dar conta de seus foras, de suas virtualidades infinitas. 
O livro de 1977 fomenta uma "leitura nordestina" não no sentido de compreender o Nordeste a partir de premissas essenciais, identitárias, nordestinóides como prefiro chamar; nordestina aqui o é por friccionar até o limite da dispersão e da rasura o estigma de uma nordestinidade sempre eternamente reinscrita, sem diferença, sem alteridade, um mesmo caminhando sempre para e por sua mesmeridade.

Macabéa, a invenção de Macabéa, de sua nordestinidade reiterante e tautológica, exige uma crítica diabolicamente nordestina, alteritária e intercultural, porque, como diria noutro contexto Roland Barthes (2007, p. 88), devemos acentuar o "caráter intolerável das relações banais" para enunciar uma fala que transforma "uma relação corrente numa relação fundamental e esta numa relação escandalosa", para que a obra seja "depositária de um imenso e incessante inquérito sobre as palavras", sobre as identidades, sobre os sujeitos; uma crítica que tenha como premissa o fato de que "a linguagem não cessa, precisamente, de alternar os papéis e de rodar as superfícies em torno de algo que, para acabar e para começar, não é".

Nordestina, portanto, é uma crítica que recusa qualquer atavismo, por essência provisória e não essencial, e que deve servir pra problematizar toda gênese apriorística e toda filiação substancialista; para rechaçar a articulação simplista que associa o Nordeste ao folclore, à natureza, à regionalidade, a formas de exterioridade sem distância, sem diferença, sem alteridade.

Uma crítica nordestina ambivalente, barroca mesmo, que trata de relação antes que de identidade. Uma crítica cindida, consciente de que "algo inelutavelmente nos escapa", que sabe que "ver é perder", que pressupõe "a temporalidade do objeto, o trabalho do tempo ou da metamorfose no objeto, o trabalho da memória - ou da obsessão - no olhar", que se recusa a "preencher o vazio pondo cada termo da cisão num espaço fechado, limpo e bem guardado pela razão - uma razão miserável, convém dizer" (Didi-Huberman, 1998, p. 34).

Assumo tal fechamento para melhor desmascará-lo, para violar seus limites na medida em que tal violação põe em xeque e sabota os narcisos da literatura e de suas formações identitárias, mas não só, cuja função principal é manter imutável a diferença num eterno, e sempre futuro, lá atrás, num intacto território definido a priori, fora de qualquer desterritorialização ou devir de singularidade. 


\section{Escrever literatura e suas crenças: a ética da escrita nos anos 1970 e alhures}

Clarice declarou, em fevereiro de 1977 numa entrevista a Julio Lerner, ${ }^{2}$ pouco antes da publicação do livro, que $A$ hora da estrela era a estória de uma "inocência pisada, de uma miséria anônima". Macabéa teria sido inspirada em sua infância no Nordeste e em uma visita que fez a uma comunidade nordestina em São Cristóvão, onde "colheu" o olhar perdido do nordestino no Rio de Janeiro.

Em muitos aspectos, Macabéa é uma resposta clariceana ao debate sobre o lugar e a função do escritor no contexto da ditatura militar, que se acirra nos anos 1970, tanto pela produção literária do período, na qual sobressai o que Malcolm Silverman chamou de "sentido de urgência" (2000), Heloísa Buarque de Holanda, de "ficção da realidade brasileira" (2005), e Flora Süssekind, de "literatura-verdade" (1985). Trata-se de uma literatura emparedada por uma demanda de engajamento, o que fez o cartunista Henfil "enterrar" Clarice Lispector em 1973 no seu quadro de O pasquim, "O cemitério dos mortos-vivos": "Eu a coloquei no 'Cemitério dos mortos-vivos' porque ela se coloca dentro de uma redoma de Pequeno Príncipe, para ficar num mundo de flores e de passarinhos, enquanto Cristo está sendo pregado na cruz" (Moraes, 2013). Ouçamos Silverman, Heloísa e Flora sobre a literatura do período:

Tanto a prosa longa quanto a curta, particularmente o conto, floresceram naquela época, como um registro histórico imediato, no que se chamaria o boom, apesar, ou talvez por causa, das medidas de repressão. Desde a ditadura Vargas, o romance jamais servira tanto de veículo para disseminar a realidade nua e cruel na qual estava imerso o país, e onde buscava sua inspiração (Silverman, 2000, p. 33).

Cresce por toda parte o desejo aguçado do testemunho, do documento, da exposição da realidade brasileira, o que, de certa forma, promove uma quase insatisfação com a narrativa literária. $\mathrm{O}$ discurso jornalístico, como técnica de referir-se ao fato, de oferecer para o leitor a realidade imediata, os esquemas de linguagem mais próprios para se dizer as urgentes verdades da história recente do país parecem agora uma saída para a literatura (Holanda, 2005, p. 119).

2 Entrevista para o Programa Panorama da TV Cultura. Disponível em: <https://www.youtube.com/watch?v=ohHP112EVnU>. Acesso em: 12 set. 2016. 
O sucesso desta literatura político-memorialista se explica, então, em parte pela tentativa desta geração mais jovem de suprir, via memória alheia, as lacunas do próprio conhecimento histórico (Süssekind, 1985, p. 44).

A hora da estrela traz muitas passagens que ironizam essa "demanda de engajamento". A "Dedicatória do autor (na verdade Clarice Lispector)" no próprio subtítulo já demarca um lugar, um lugar de indecidibilidade entre vida e obra, entre o autor e seu narrador, mas que, quero crer, não pode ser avaliado, como o fez a grande crítica da autora que se dedicou a discorrer sobre o livro de 1977, a partir de uma relação exclusivamente semiótica, do problema da semiotização do real, problema tão velho, convenhamos, quanto a própria literatura.

Ela demarca, principalmente, o lugar da obra em relação a seu presente, a seus leitores, à intelectualidade brasileira do período, "a todos que em mim atingiram zonas assustadoramente inesperadas, todos estes profetas do presente e que a mim vaticinaram a mim mesmo a ponto de eu neste instante explodir em: eu" (1981, p. 7). Flora Süssekind chamará atenção para essa natureza compensatória da literatura do período, alvo da mordaz ironia clariceana.

Uma ironia que aponta para fora, mas prolifera a instância do dentro, da individualidade desdobrada ao infinito - a mim, a mim mesmo, de eu explodir em eu -, as referências ao lugar do escritor e de sua escrita, das possibilidades de sua escrita como "representação" da alteridade, que se joga com o embotamento da fronteira entre o "autor e o herói" - "em menino me criei no nordeste" ou "a minha vida a mais verdadeira é irreconhecível, extremamente interior e não tem uma só palavra que a signifique" (1981, p. 15), o que me faz concluir que a indecidibilidade entre ambos é o "tema" principal da obra e a literatura, seu protagonista.

A ironia pressupõe a ultrapassagem, a dobradura, da relação habitual entre um significante e seus significados pertinentes, pressupondo instâncias avaliadoras a partir das quais significados não pertinentes afloram. Desdobrar significados sob um mesmo significante é o fundamento de todo discurso irônico, na medida em que a ironia só o é enquanto relação de significados potenciais, atualizáveis pela comunidade discursiva interlocutora. É por isso que a ironia é sempre legião, de aspectos semióticos, históricos, sociais, culturais e políticos (Hutcheon, 2000). 
Assim, ela é, direta ou indiretamente, trânsito entre comunidades discursivas que o significante vicário tende a manter separadas. Em outras palavras, ela nunca poderá ser compreendida no interior de uma única comunidade discursiva preferencial, ela pressupõe um fora, uma outra instância em relação à qual ela funciona. É esta interdiscursividade inescapável à ação irônica que faculta um aporte intercultural, pois um mesmo discurso irônico pode ser crítico em sua relação com uma comunidade discursiva à custa de reencenar e atualizar valores hegemônicos em outra. Em outras palavras, a natureza proliferante da ironia pode, a um só tempo, torná-la politicamente desconstrutora em uma comunidade e conservadora em outra.

De certo modo, a melhor crítica de $A$ hora da estrela percebeu esse aspecto desconstrutor da ironia, mas apenas como crítica contundente à literatura-verdade, ao romance-reportagem de José Loureiro e aos relatos da tortura e da luta política, em Renato Tapajós e Fernando Gabeira, por exemplo, sendo Macabéa uma crítica radical à heroicização da personagem, comum na prosa do período. Mas a ênfase dada a esse aspecto da obra, sem dúvida da maior relevância, sem que se problematize a própria semiotização da "ralé brasileira", para usar a expressão de Jessé de Souza, e que motiva a escrita do livro, não dá conta de sua constitutiva ambivalência quanto às relações efetivas do encontro com a alteridade e, por extensão, com suas premissas interculturais. Em outras palavras, se o discurso irônico indiscutivelmente acerta o alvo do realismo estreito do período, é possível dizer o mesmo da semiotização do Nordeste e da suposta nordestinidade de Macabéa?

Tal ambivalência, tagarela por um lado e silenciante por outro, situa-se no limiar, completamente inexplorado pela melhor crítica clariceana, entre uma ética da escrita e uma ética do encontro com a alteridade. A primazia dada à ética da escrita pela crítica tem o grande mérito de expor a superficialidade e, em alguns casos, o oportunismo editorial e político de muitos dos livros do período, acentuando o caráter paratópico e paradoxal do próprio lugar do escritor num mundo muito afeito a urgências que não são necessariamente democratizadoras, mas muitas vezes integradas a uma cultura do consumo, parte indissociável de certa espetacularização da violência e da própria mercadoria.

Contudo, esse viés, esse produtivo e instigante viés, também pode servir a dois senhores, sendo o outro o próprio narcisismo da literatura e da crítica, seu fechamento numa autonomia portadora de certa 
indiferença com essa coisa mesquinha chamada inapropriadamente de "realidade", na medida em que a supremacia do tratamento imanente da literatura, do problema da literatura e da representação literária na crítica, é fruto, também, daquilo que Michel Foucault (2001) chamou de "função classificatória" da instância autoral, uma função-autor chamada Clarice Lispector, que a preserva de todo compromisso por demais historicizante, e "permite reagrupar um certo número de textos, delimitá-los, deles excluir alguns, opô-los outros" (Foucault, 2001, p. 278). Em outras palavras, preserva um lugar de pertinência contra toda invasão "excêntrica" de seu contexto histórico.

Ainda com Foucault (2001, p. 279), digo que a preferência pela abordagem imanente e autônoma da literatura, dos problemas da literatura, permite à crítica clariceana manter "o princípio de uma certa unidade de escrita", que revela tanto mais sobre a obra quanto sobre as próprias estratégias de leitura da crítica. Digo mais, permite à crítica invisibilizar, na medida mesma em que opera n'A hora da estrela com os princípios norteadores da leitura de outras obras da autora, a incômoda presença de uma alteridade incontornável, Macabéa e sua "nordestinidade".

O que estou chamando de ética da escrita e de protagonismo da literatura como vetor da obra é corroborado pelo lugar que nela ocupam as referências à música. Logo na significativa dedicatória lê-se: "dedico esta coisa aí ao antigo Schumann e sua doce Clara que são hoje ossos, ai de nós" (Lispector, 1981, p. 7), e, em seguida:

Dedico-me à tempestade de Beethoven. À vibração das cores neutras de Bach. A Chopin que amolece os ossos. A Stravinsky que me espantou e com que voei em fogo. A "Morte e transfiguração" em que Richard Strauss me revela um destino? Sobretudo dedicome às vésperas de hoje e a hoje, ao transparente véu de Debussy, a Marlos Nobre, a Prokofiev, a Carl Orf, a Schonberg, aos dodecafônicos, aos gritos rascantes dos eletrônicos (Lispector, 1981, p. 7).

É sabido, desde a segunda metade do séc. XIX, o quanto a música serviu de contraponto à imposição realista, à falácia causalista do naturalismo, fundada na transparência entre signo e referência, entre literatura e contexto histórico imediato. A utopia da música sob o simbolismo - de Verlaine a Mallarmé e alhures - assume a forma de uma oposição radical a toda literatura-verdade. Sem as imposições da dupla articulação, linguagem da alusão e do "sentimento", a música serve para 
depor a ilusão objectualista que incide sobre a arte literária e sua inesgotável liberdade de criação.

Se a literatura do período acionava "a paixão do leitor pelas cenas teatralmente dolorosas, pela exibição literal, alegórica e entrecortada de suas chagas políticas" (Süssekind, 1985, p. 46), n'A hora da estrela, a música retira o signo de seu ordenamento de espelho do real e o coloca ao lado "de todas as linguagens que desterritorializam, colocam em fuga as constantes da máquina abstrata da língua em prol de um devir potencial que se desvia do modelo" (Santaella, 2001, p. 102). Embora pensando noutro contexto, Vladimir Safatle $(2008$, p. 183) chega à mesma conclusão: "A música teria imposto, às outras artes, uma noção de modernidade e de racionalização do material vinculada à autonomização da forma e de suas expectativas construtivas". Em resumo, a referência à música como utopia da forma autônoma permite à literatura evitar a armadilha das "afinidades miméticas".

No contexto dos anos 1970, Clarice recoloca a música como metáfora para salvaguardar o "devido lugar" da literatura: "o círculo estreito das obras 'intransitivas', que exprimem a 'visão de mundo' singular de um criador soberano" (Maingueneau, 2006, p. 59). Em outras palavras, o protagonismo da autonomia literária que $A$ hora da estrela aciona ou repropõe em nova base tem na jogada discursiva da ironia do narrador e da indecibilidade entre sua voz e a voz da autora - "na verdade Clarice Lispector" - sua instância política explícita e sua diferença em relação à literatura do período.

Contudo, na medida em que toda ironia pressupõe um acréscimo de significação, ela só pode se dar a partir de um certo pacto interpretativo, ela exige uma "comunidade suplementar" que faz o discurso desdobrar sobre si mesmo, que faz o significante deambular para além do significado. Uma tal jogada se torna entrópica quanto confrontada com uma comunidade que não necessariamente acata as premissas que semiotizam Macabéa e sua nordestinidade como uma segunda natureza, ironicamente assumindo a transparência signo/referência que a ironia tentou desqualificar.

Macabéa e sua nordestinidade tornam-se, assim, não apenas um entrave para todo realismo estreito, ela é um entrave pra própria literatura e sua autonomia, para sua musicalização, digamos um tanto ironicamente. Mas ela só é na medida em que $A$ hora da estrela formula a alteridade de sua personagem a partir das mesmas bases heurísticas que 
fundamentam a representação do Nordeste brasileiro desde Euclides da Cunha e que, como tentarei mostrar, a ironia não alcança, ou não alcança se tomada por uma leitura "local", que rechaça toda vinculação essencializante do que hoje podemos chamar de devir multiplicidade do Nordeste brasileiro e de suas formas de vida.

Em outras palavras, se a ironia faz deambular a relação vicária entre significante e significado, no que diz respeito a Macabéa, é o próprio pacto que funda a significação do discurso irônico que se torna problemático se lido a partir da perspectiva da própria alteridade implicada.

\section{Macabéa e o primado epistemológico da relação}

Em Presenças do outro (2002), Eric Landowski propõe uma sociossemiótica que parta do "primado epistemológico da relação" sobre a identidade. Ele vai buscar em Saussure o princípio segundo o qual "só se podem identificar unidades pela observação das diferenças que as interdefinem" (Landowski, 2002, p. 1). Para ele, identidade e alteridade são "diferenças posicionais" (2002, p. 12) e não podem ser definidas substancialmente. Em outras palavras, não devemos pensá-las numa perspectiva ontológica, mas eco-lógica, o outro é uma questão de espaço e de posicionamento.

O que dá forma à minha própria identidade não é o que defino para mim mesmo, mas transitivamente a partir do conteúdo que atribuo à alteridade do outro e à diferença que o separa de mim. Em resumo, "a emergência do sentido de 'identidade' parece passar necessariamente pela intermediação de uma 'alteridade' a ser construída” (Landowski, 2002, p. 4).

Macabéa só é pensável numa perspectiva do fora, do "primado epistemológico da relação", da literatura como um agenciamento coletivo que opera com outras formações discursivas e diferentes modos de vida e gestão cultural, aparatos sociais e afetivos vários. Ela exige uma nova crítica, nova crítica que, ao contrário da antiga, não fecha a literatura em si mesma, mas quer saber "com o que ela funciona, em conexão com o que ela faz ou não passar intensidades, em que multiplicidades [ela] se introduz e metamorfoseia a sua", na conhecida provocação de Gilles Deleuze e Félix Guattari (1995, p. 12).

Para dar conta dela, é necessário tirar a literatura de sua tautologia, porque em se tratando de $A$ hora da estrela, arrisca-se deixar intacta uma 
grade interpretativa que faz o mesmo retornar incessantemente ao mesmo, uma "semiocracia" do tipo descrito por Daniel Castillo Durante (2007, p. 5):

Desde sempre, no Ocidente a alteridade passa através das grades de representação que produzem imagens, cuja função principal é manter imutável a diferença. A literatura, as práticas visuais, a música, o cinema, a arquitetura constroem aparatos interpretativos do outro que pertencem a uma semiocracia, ou seja, a um horizonte de sentido único. É esta semiocracia que sumariamente desde Ulisses permite ao mesmo voltar ao lar com imagens exóticas como despojos. Com efeito, o mito que alicerça a epopeia grega, um dos textos fundadores do pensamento ocidental, põe em relevo o retorno do sujeito a sua concha identitária, apesar de uma travessia difícil que supostamente o fez passar pelas provas do outro. A volta de Ulisses a sua terra de origem significa assim essencialmente a volta do mesmo ao mesmo.

Assim, Macabéa só pode ser compreendida por um gesto de "desobediência epistêmica", não só em relação à literatura e aos movimentos dominantes de sua crítica, mais além, como sugere Walter Mignolo (2008, p. 304), "pensar a partir da exterioridade e em uma posição epistêmica subalterna vis-à-vis à hegemonia epistêmica que cria, contrói, erege um exterior a fim de assegurar a sua interioridade".

Teria a crítica, a melhor crítica clariceana, erigido esse exterior para melhor recolocar sua própria, da crítica, da literatura e da funçãoautor Clarice Lispector, interioridade?

Pensar Macabéa na perspectiva do diálogo intercultural exige um aporte político, para além do literário e, por extensão, do exclusivamente "cultural", na medida em que implica relações aporísticas, contraditórias, inseridas em relações sociais desiguais. $\mathrm{O}$ lugar de Macabéa, o modo de semiotização da mulher retirante nordestina pobre - abundam os adjetivos - confirma a hipótese intercultural de Claude Corbo (1997, p. 71), "as culturas [e a literatura como parte delas] existem em um espaço político e carregam, com uma intensidade e força variável, a potência econômica, tecnológica, militar e política das nações" e de seus grupos.

Sob esse aspecto, o intercultural pressupõe a consciência de uma articulação não harmônica de agências de vários tipos, econômicas e sociais, de projetos de vida individuais e coletivos, de afetos, de técnicas e tecnologias, de modos de representação e de tradições 
diversas, que não podem ser subsumidas a locações simples, entre os quais devemos dar especial atenção à semiotização dos pobres "quem não possui nome ou direito à palavra pública" (Breaugh, 2010, p. 384) - e de sua produção de subjetividade.

Se o espaço ocupado por Macabéa em $A$ hora da estrela é novo na poética da autora, os pobres não deixam de ser recorrentes nela. Foi Luiza Lobo quem chamou atenção para a posição dos pobres em Clarice Lispector: "É este ser escuro e escondido, geralmente uma africana, a empregada, quem permite à patroa ser, pensar, existir, e até mesmo ser escritora" (Lobo, 2007, p. 39). Em outras palavras, se A hora da estrela abre uma nova fase da poética da autora, o modo de conceber os "seres obscuros e escondidos" não difere dos contos de Laços de família, A legião estrangeira, Onde estivestes de noite, A via crucis do corpo e da empregada Janair de A paixão segundo G.H.

Assim, A hora da estrela tanto se afasta quanto se mantém sem maiores obstáculos na poética da autora, a ambivalência aqui se dá em maior proporção que nas outras narrativas, curtas ou longas, porque se há indecidibilidade entre autor e herói, a partir de onde se enuncia o problema da própria representação literária, o estatuto de Macabéa não possui ambivalência alguma, não se constitui como devir, mas como um sujeito atolado em sua própria sujeição, em um essencial atavismo: "ela era subterrânea e nunca tinha tido floração. Minto: ela era capim" (Lispector, 1981, p. 38).

$\mathrm{N}^{\prime}$ A hora da estrela, sendo a literatura e sua relação com o real um problema sempre posto, Macabéa e sua identidade nordestina não se apresentam como problema, como opacidade inerente à toda alteridade, antes não portam nenhuma densidade, "nenhum segredo", nenhuma potência alteritária, ela é o que é: “a pessoa de quem falarei mal tem corpo para vender, ninguém a quer, ela é virgem e inócua, não faz falta a ninguém" (Lispector, 1981, p. 18). Nos momentos de maior tensão, o incômodo se dá sempre entre a literatura, seus jargões e seus habitus, em confronto com este ser que não é nada além de si mesma, sem densidade, sem devir:

Como todo escritor, tenho a tentação de usar termos suculentos: conheço adjetivos esplendorosos, carnudos substantivos e verbos tão esguios que atravessam agudos o ar em vias de ação, já que palavra é ação, concordais? Mas não vou enfeitar a palavra, pois se eu tocar no pão da moça se tornará em ouro - e a jovem (ela 
tem dezenove anos) e a jovem não poderia mordê-lo, morrendo e fome. Tenho então que falar simples para captar a sua delicada e vaga existência (Lispector, 1981, p. 19).

Por que esta existência é tão delicada e vaga? Pela sua diferença essencial do narrador Rodrigo S.M.: "ela como uma cadela vadia era teleguiada exclusivamente por si mesma. Pois reduzia-se a si. Também eu, de fracasso em fracasso, me reduzi a mim mas pelo menos quero encontrar o mundo e Deus" (Lispector, 1981, p. 23).

Na medida em que uma relação intercultural "remete à confrontação e ao entrelaçamento, àquilo que sucede quando os grupos entram em relações e trocas" (Canclini, 2009, p. 21), não se pode aqui falar de relação intercultural alguma, pois a relação só serve para afirmar o "outro" do mesmo; é a ele, e por extensão à própria literatura, que cabe o direito à diferença como criação, à produção da diferença como contínuo processo de vir a ser, não a Macabéa, atolada num eterno presente habitado de nuncas.

Ao contrário, ela se situa numa "zona de não ser" de que fala Frantz Fanon (2008, p. 26), "uma região extraordinariamente estéril e árida". Macabéa não é um sujeito em devir de diferenciação ininterrupta, assim é Rodrigo S.M., como todas as protagonistas claricenas; Macabéa é uma essência pré-discursiva que o discurso engendra como tautologia, um corpo abjeto que se depara com corpos humanos. Em outras palavras, Macabéa não tem nenhuma potência imaterial, não tem "alma", não tem "direito epistêmico", seu saber não pode, na ética da escrita de Rodrigo S.M., inventar mundos fora do mundo, mas apenas subcultura, animalidade.

Ela é formulada em termos incomodamente análogos aos dos muitos animais recorrentes na obra da autora. Em A paixão segundo G.H. lê-se: "Qual é o único sentimento de uma barata? A atenção de viver, inextricável de seu corpo" (Lispector, 1991, p. 35). E conclui, criando um nexo entre a empregada Janair e a asquerosa barata: "E agora eu entendia que a barata e Janair eram os verdadeiros habitantes do quarto" (Lispector, 1991, p. 33). Os termos utilizados para caracterizar a conhecida galinha do conto do mesmo nome poderia muito bem ser transposto para Macabéa: "não olhava para ninguém, ninguém olhava para ela. Mesmo quando a escolheram, apalpando sua intimidade com indiferença, não souberam dizer se era gorda ou magra" (Lispector, 1993a, p. 43). Mas, diferentemente da galinha, Macabéa, o bicho-Macabéa - "meu Deus, era um homem" -, não tem qualquer ponto de fuga: "foi pois uma surpresa quando a viram 
abrir as asas de curto voo, inchar o peito e, em dois ou três lances, alcançar a murada do terraço" (Lispector, 1993a, p. 43).

Definida nos mesmos termos dos animais, sem, contudo, possuir a iluminação profana que estes facultam às personagens, Macabéa é inferior a eles. Enquanto o narrador, Rodrigo S.M., vive num devir agônico entre muitas maneiras possíveis da construção de si, Macabéa e seu Nordeste natal estão numa simbiose sem fora, obedientes a uma tradição discursiva estigmatizante que homogeneiza a diferença, em hipótese alguma questionada, duvidada, problematizada pela ironia do narrador:

Nascera inteiramente raquítica, herança do sertão - os maus antecedentes de que falei. Com dois anos de idade lhe haviam morrido os pais de febres ruins no sertão de Alagoas, lá onde o diabo perdera as botas. Muito depois fora para Maceió com a tia beata, única parente sua no mundo. Uma ou outra vez se lembrava de coisa esquecida (Lispector, 1981, p. 35).

Algumas palavras-chave do velho Nordeste: raquítica, herança, maus antecedentes, febres, diabo, tia beata, coisa esquecida. Macabéa é indicialoide, possui apenas rudimentos de memória: "vivia em tanta mesmice que de noite não se lembrava do que acontecia de manhã" (Lispector, 1981, p. 40). Ou, "ria por não ter se lembrado de chorar" (Lispector, 1981, p. 65). O narrador conclui: "Tentara contar a Gloria mas não tivera jeito, não sabia falar e mesmo contar o quê?".

"Uma vez que falar é existir absolutamente para o outro" (Fanon, 2008, p. 33), destituída de signo e de memória, ela inexiste para o outro, a não ser como objetualidade sem densidade, sem metáfora, sem alegoria. Dito de outra maneira, se em Rodrigo S.M. se pode, sem reservas, falar de crise da representação e de busca incessante de si mesmo em sua relação com a realidade e seus outros, não há hiato entre linguagem e realidade, entre signo e representação quanto a Macabéa. No que diz respeito a ela, tudo é transparência e mimesis, onde a ironia não é pertinente, não alcança desconstruir a relação vicária entre significante e significado.

Sob este aspecto, Macabéa é o extremo oposto de todas as grandes personagens clariceanas, como G.H. e a emblemática Ana, de Amor, cujos devires vegetais e animais e suas consequências justificam a longa citação:

Inquieta, olhou em torno. Os ramos se balançavam, as sombras vacilavam no chão. Um pardal ciscava na terra. E de repente, com 
mal-estar, pareceu-lhe ter caído numa emboscada. Fazia-se no Jardim um trabalho secreto do qual ela começava a se aperceber. Nas árvores as frutas eram pretas, doces como mel. Havia no chão caroços secos cheios de circunvoluções, como pequenos cérebros apodrecidos. O banco estava manchado de sucos roxos. Com suavidade intensa rumorejavam as águas. No tronco da árvore pregavam-se as luxuosas patas de uma aranha. A crueza do mundo era tranquila. $\mathrm{O}$ assassinato era profundo. E a morte não era o que pensávamos. Ao mesmo tempo que imaginário - era um mundo de se comer com os dentes, um mundo de volumosas dálias e tulipas. Os troncos eram percorridos por parasitas folhudas, o abraço era macio, colado. Como a repulsa que precedesse uma entrega - era fascinante, a mulher tinha nojo, e era fascinante. As árvores estavam carregadas, o mundo era tão rico que apodrecia. Quando Ana pensou que havia crianças e homens grandes com fome, a náusea subiu-lhe à garganta, como se ela estivesse grávida e abandonada. A moral do Jardim era outra. Agora que o cego a guiara até ele, estremecia nos primeiros passos de um mundo faiscante, sombrio, onde vitórias-régias boiavam monstruosas. As pequenas flores espalhadas na relva não lhe pareciam amarelas ou rosadas, mas cor de mau ouro e escarlates. A decomposição era profunda, perfumada... Mas todas as pesadas coisas, ela via com a cabeça rodeada por um enxame de insetos, enviados pela vida mais fina do mundo. A brisa se insinuava entre as flores. Ana mais adivinhava que sentia o seu cheiro adocicado... O Jardim era tão bonito que ela teve medo do Inferno (Lispector, 1993b, p. 16).

Os processos de desterritorialização de Ana geram um suplemento que enriquece a experiência sempre em processo de ser, um devir outro que se exprime e se escreve em muitas epifanias. Em sentido oposto, Macabéa é um "ser-aí", incapaz de romper seu próprio casulo. Se "a liberdade é a condição ontológica da ética", como sugeriu Michel Foucault (2004, p. 267), sob o olhar de Rodrigo S.M., Macabéa não é só destituída de liberdade, ela é destituída de existência ética.

Retomando o Landowski anteriormente aludido, pode-se com isso afirmar que o que dá forma à identidade de Rodrigo S.M. é menos o que ele define para si mesmo, mas, transitivamente, o conteúdo que atribui à alteridade de Macabéa e à diferença que a separa dele. Macabéa é ao mesmo tempo o outro que falta e o outro que sobra, o suplemento indispensável por descartabilidade, aquele cuja invocação cria nele uma 
incompletude ou um impulso semiósico, "porque sua não presença atual [o] mantém em suspenso e como que inacabado" (Landowski, 2002, p. 13), na medida mesma em que ela é "a caracterização grosseira e indiscriminada do grupo estranho, em que as multiplicidades e as diferenças individuais são apagadas, em nome de semelhanças superficiais do grupo" (Albuquerque Jr., 2001, p. 20).

A leitura nordestina d'A hora da estrela compreende, assim, os processos de semiotização a que é subsumida Macabéa como um logro, "engano e erro", no sentido que deu a esses dois termos Eduardo Viveiros de Castro, pois "supõem premissas já constituídas como homogêneas" (Castro, 2015, p. 92). Falta à semiotização de Macabéa uma ética tradutória que dê conta da "positividade relacional da diferença", a assunção do equívoco como uma dimensão constitutiva do diálogo intercultural:

O equívoco não é o que impede a relação, mas aquilo que a funda e a propele: uma diferença de perspectiva. Traduzir é presumir que há desde sempre e para sempre um equívoco; é comunicar pela diferença, em vez de silenciar o Outro ao presumir uma univocidade originária e uma redundância última - uma semelhança essencial entre o que ele e nós "estávamos dizendo" (Castro, 2015, p. 91).

Assim, em relação à Macabéa, e por extensão a Olímpio, seu namorado também nordestino, Rodrigo S.M. se concebe como a identidade legítima, que presume a "unicidade originária" dela, de tal sorte que a alteridade só pode aparecer como uma ameaça vinda de fora, mesmo que essa ameaça seja unicamente à literatura e a seus modos de representação (relevante problema que precisa ser discutido), não como diferença posicional, mas essencial. Ou, o que dá no mesmo, essencial por ser posicional, o Nordeste e seus estigmas.

Concluo aqui com algumas obviedades que, enquanto tais, precisam ser reiteradas: não tenho pretensão alguma de dar a última palavra, a palavra-moral, sobre A hora da estrela e sua incômoda personagem. Apenas recuso-me a aceitar, sem aporia, a semiotização da diferença nos termos imanentes, no pior sentido da palavra, da própria literatura e da força da função autor-Clarice Lispector, muitas vezes usada à revelia dela mesma, seja lá quem ela não for ou tenha não sido. Não pressuponho, ainda, uma total transparência na inumanidade de tal semiotização, antes, a vejo como também cindida, ambivalente, paradoxal, mas por isso mesmo passível de uma ética da leitura que a exponha. Recuso-me também a inverter os termos, supervalorizar uma suposta humanidade de Macabéa, 
defendendo sua identidade e sua territorialização com uma outra utopia positivante, tão etnocêntrica quanto sua conformação no estigma.

Antes, a crítica nordestina que proponho não quer "apagar contornos, mas dobrá-los, adensá-los, enviesá-los" (Castro, 2015, p. 28), porque, parafraseando Eduardo Viveiros de Castro, aqui ninguém é nordestino, exceto quem é.

Clarice exige de nós, hoje, que enviemos, a partir de sua grande obra, essa imagem monstruosa dela mesma, do que ela não é, sendo.

\section{Referências}

ADORNO, Theodor (1988). Teoria estética. Lisboa: Edições 70.

ALBUQUERQUE JÚNIOR, Durval Muniz de (2001). A invenção do Nordeste. 2. ed. São Paulo: Cortez.

BARTHES, Roland (2007). Crítica e verdade. Lisboa: Edições 70.

BREAUGH, Martin (2010). A experiência da plebe. In: DIAS, Bruno Peixe; NEVES, José (Coord.). A politica dos muitos: povo, classes, multidão. Lisboa: Fundação EDP, p. 379-392.

CANCLINI, Nestor-García (2009). Teorias da interculturalidade e fracassos políticos. In: CANCLINI, Nestor-García. Diferentes, desiguais e desconectados. Rio de Janeiro: UFRJ, p. 15-33.

CASTRO, Eduardo Viveiros de. Metafísicas canibais. São Paulo: Cosac Naify, 2015.

CORBO, Claude (1997). Conditions politiques et conditions culturelles du dialogue interculturel. In: LABSADE, Françoise Tétu. Littérature e dialogue interculturel. Québec: PUL, p. 69-78.

DELEUZE, Gilles; GUATTARI, Félix (1995). Mil platôs. v. 1. São Paulo: Editora 34.

DIDI-HUBERMAN, Georges (1998). A inelutável cisão do ver. In: DIDIHUBERMAN, Georges. O que vemos, o que nos olha. São Paulo: Editora 34, p. 34.

DURANTE, Daniel Castillo (2007). Alteridade e reflexão intercultural: seus objetivos no quadro das praticas artísticas em geral e da fala literária em particular. Sociopoética, Campina Grande, v. 1, n. 1, p. 1-16.

FANON, Frantz (2008). Pele negra, máscaras brancas. Salvador: Edufba.

FOUCAULT, Michel (2001). O que é um autor? In: FOUCAULT, Michel. Estética: literatura e pintura, música e cinema. Rio de Janeiro: Forense Universitária, p. 264-298. 
FOUCAULT, Michel (2004). Ditos e escritos: ética, sexualidade, política. São Paulo: Forense Universitária.

HOLANDA, Heloísa Buarque de (2005). A ficção da realidade brasileira. In: NOVAES, Adauto (Org.). Anos 70: ainda sob a tempestade. Rio de Janeiro: Editora SENAC, p. 97-159.

HUTCHEON, Linda (2000). Teoria e política da ironia. Belo Horizonte: Editora da UFMG.

LANDOWSKI, Eric (2002). Presenças do outro. São Paulo: Perspectiva.

LISPECTOR, Clarice (1991). A paixão segundo G. H. 12. ed. Rio de Janeiro: Francisco Alves.

LISPECTOR, Clarice (1993a). Uma galinha. In: LISPECTOR, Clarice. Laços de família. 24. ed. Rio de Janeiro: Francisco Alves, p. 43-46.

LISPECTOR, Clarice (1993b). Amor. In: LISPECTOR, Clarice. Laços de família. 24. ed. Rio de Janeiro: Francisco Alves, p. 16-17.

LISPECTOR, Clarice. A hora da estrela (1981). 6. ed. Rio de Janeiro: José Olympio.

LOBO, Luiza (2007). Clarice Lispector e Virginia Woolf. In: LOBO, Luiza. Crítica sem juízo. 2. ed. Rio de Janeiro: Garamond, p. 34-50.

MAINGUENEAU, Dominique (2006). Discurso literário. São Paulo: Contexto.

MIGNOLO, Walter (2008). Desobediência epistêmica: a opção descolonial e o significado de identidade em política. Cadernos de Letras da UFF, Niterói, n 34, p. 287-324.

MORAES, Dênis de (2013). O humor de Henfil contra quem oprime. Blog da Boitempo, São Paulo, 5 jun. On-line. Disponível em: https://goo.gl/P5YVss

NUNES, Benedito (2009). O dorso do tigre. São Paulo: 34.

PORTELLA, Eduardo (1981). O grito do silêncio. In: LISPECTOR, Clarice. A hora da estrela. 6. ed. Rio de Janeiro: José Olympio, p. 9.

SAFATLE, Vladimir (2008). O esgotamento da forma crítica como valor estético. In: SAFATLE, Vladimir. Cinismo e falência da crítica. São Paulo: Boitempo, p. 179-201.

SANTAELLA, Lucia (2001). A matriz sonora e suas modalidades. In: SANTAELLA, Lucia. Matrizes da linguagem pensamento: sonora, visual, verbal. São Paulo: Iluminuras, p. 97-184.

SILVERMAN, Malcolm (2000). Protesto e o novo romance brasileiro. Civilização Brasileira.

SOUZA, Jessé (2011). A ralé brasileira: como pensa e como vive. Belo Horizonte: UFMG, p. 24. 
SÜSSEKIND, Flora (1985). Literatura e vida nacional: polêmicas, diários e retratos. Rio de Janeiro: Jorge Zahar.

Recebido em 7 de novembro de 2016.

Aprovado em 26 de janeiro de 2017.

\section{resumo/abstract/resumen}

\section{A hora da estrela: por uma leitura nordestina}

Luciano Barbosa Justino

Meu objetivo neste artigo é pensar A hora da estrela, de Clarice Lispector, a partir de duas instâncias éticas: uma da escrita e da literatura e outra do encontro incontornável com a alteridade, ambas à luz do que estou chamando de uma crítica nordestina. Na primeira, pretendo discorrer sobre as relações da obra com o contexto brasileiro dos anos 1970 e como Clarice Lispector responde a uma "demanda de engajamento", problematizando e reinscrevendo a literatura e sua autonomia em face de um contexto por demais pregnante; na outra, objetivo demonstrar como a primeira se constitui sobre uma delimitação precisa, identitária, da alteridade de Macabéa e de sua nordestinidade.

Palavras-chave: literatura brasileira contemporânea, ética da escrita, alteridade, interculturalidade, Clarice Lispector.

\section{The hour of the star: for a Northeastern reading}

Luciano Barbosa Justino

My objective in this article is to think about The hour of the star by Clarice Lispector in light of what I denominate two ethics. The first references the written word and literary production. The second touches upon the inexorable encounter with the other. Both ethics are guided by an intercultural perspective. In the first ethic, I intend to discuss the novel's relations with the Brazilian context of the 1970's and how Clarice Lispector responds to the demand of "engagement" by questioning and re-inscribing literature and its autonomy within an emphatic context. In the second ethic, I intend to demonstrate how the first constitutes itself in relation to the agonizing encounter with Macabéa's otherness and her northeastern mode of expression.

Keywords: contemporary Brazilian literature, writing ethics, otherness, interculturalism, Clarice Lispector. 


\section{A hora da estrela: por una lectura nordestina}

Luciano Barbosa Justino

El presente artículo tiene por objetivo reflexionar sobre la obra A hora da Estrela de Clarice Lispector a partir de dos posiciones éticas: por un lado desde la escritura y la literatura y por el otro del encuentro inevitable con la alteridad, ambas a la luz de lo que llamo una crítica nordestina. En primer lugar hablo de las relaciones de la obra con el contexto brasileño de los años setenta y cómo Clarice Lispector responde a la "demanda de participación", planteando preguntas y reescribiendo la literatura y su autonomía frente a un contexto demasiado pregnante; en segundo lugar, tengo por objetivo presentar cómo ésta primera aproximación se constituye sobre una delimitación precisa, identitaria, de la alteridad de Macabéa y de la defensa de sus rasgos nordestinos.

Palabras clave: literatura brasileña contemporánea, ética de la escritura, alteridad, interculturalidad, Clarice Lispector. 